\title{
Inter and intratumour heterogeneity: a barrier to individualized medical therapy in renal cell carcinoma?
}

\author{
Rosalie Fisher ${ }^{1}$, James Larkin' and Charles Swanton ${ }^{2 *}$ \\ ' Department of Medical Oncology, The Royal Marsden Hospital, London, UK \\ Translational Cancer Therapeutics Laboratory, Cancer Research UK London Research Institute, London, UK \\ *Correspondence: charles.swanton@cancer.org.uk
}

\section{MEDICAL THERAPY FOR RCC IN 2012}

There are nearly 9000 new diagnoses of renal cell carcinoma (RCC) each year in the United Kingdom, and nearly 60,000 in the United States (Jemal et al., 2010; UK, 2011; Jemal et al., 2010; Cancer Research UK, 2011). Nephrectomy for localized disease may be curative, but $\sim 50 \%$ of patients present with or subsequently develop metastatic disease (Motzer et al., 1996; Leibovich et al., 2003), which is inevitably fatal. In general, these patients require palliative systemic therapy, but metastatic RCC (mRCC) has historically been refractory to cytotoxic and hormonal therapy (Harris, 1983; Yagoda and Bander, 1989). Prior to 2007, immunotherapy with interferon-alpha or interleukin-2 was the mainstay of treatment, with modest benefits at best (Motzer et al., 2002b; Coppin et al., 2005). Since then, seven molecularly targeted agents have been approved for use in mRCC, all of which have been shown in phase III randomized clinical trials to improve disease control and which now represent the standards of care (Escudier et al., 2007a,b; Hudes et al., 2007; Motzer et al., 2007, 2010; Rini et al., 2008, 2011; Sternberg et al., 2010). Sunitinib, sorafenib, pazopanib, and axitinib are orally administered inhibitors of multiple tyrosine kinase receptors, with variable affinity for the vascular endothelial growth factor receptor (VEGF-R), and provide tumor control through suppression of angiogenesis, as does the monoclonal antibody to VEGF, bevacizumab. Temsirolimus and everolimus are mammalian target of rapamycin (mTOR) inhibitors; the mTOR pathway is a key component of the $\mathrm{PI} 3 \mathrm{~K} /$ Akt pathway which mediates tumor cell proliferation and survival via cell cycle regulatory proteins (Schmelzle and Hall, 2000; Fingar et al., 2004) and is also thought to influence angiogenesis (Del Bufalo et al., 2006; Thomas et al., 2006). A therapeutic approach which targets critical biological signaling pathways has clearly been the most successful strategy to treat mRCC to date, however, anti-VEGF and anti-mTOR treatments remain inadequate. Furthermore, individualized therapy for mRCC has not been achieved; resistance to treatment is a major problem for which the molecular basis has not been determined, and biomarkers predictive of response or resistance have not been developed.

\section{THE CLINICO-PATHOLOGICAL DIVERSITY OF RCC}

Renal cell carcinoma is comprised of distinct pathological subtypes, which to some degree influence tumor behavior. The predominant subtype, clear cell RCC, accounts for $75 \%$ of RCCs (Reuter, 2006), and patients with this histology were almost exclusively enrolled in the registration trials for the drugs described above. There is much research into the molecular pathogenesis of clear cell RCC, which is characterized by loss of function in the Von Hippel-Lindau (VHL) gene leading to accumulation of hypoxia-inducible factor (HIF) and a panel of hypoxia-responsive genes such as VEGF (Kim and Kaelin, 2004; Kaelin, 2007). Germline mutations in the MET oncogene are associated with Hereditary Papillary Renal Carcinoma (HRPC) and this gene may also be activated in sporadic Type I papillary RCC (Schmidt et al., 1997; Lubensky et al., 1999). Familial forms of Type 2 papillary RCC result from germline mutations in genes encoding metabolic enzymes, such as the Krebs cycle enzymes fumarate hydratase $(F H)$ and succinate dehydrogenase B (SHDB; Toro et al., 2003; Ricketts et al., 2008). The remaining subtypes - chromophobe, collecting duct, translocation, medullary and mucinous tubular, and spindle cell carcinomas include some rare entities but there is still considerable knowledge about their pathobiology. Specifically, chromophobe RCCs can occur with hair follicle hamartomas and pulmonary cysts as part of the autosomal dominant Birt-Hogg-Dubé syndrome, caused by mutations in the BHD gene FLCN
(Nickerson et al., 2002), and KIT has been reported to be overexpressed in the sporadic form of this subtype (Yamazaki et al., 2003; Pan et al., 2004; Yusenko et al., 2009). Translocation tumors are characterized by a breakpoint at chromosome Xp11 and gene fusions between TFE3 transcription factor and multiple genes (Martignoni et al., 2009).

Diversity of clinical outcomes in RCC may partly reflect this pathological variation. For example, papillary and chromophobe tumors appear to be less likely to metastasise than clear cell tumors (Leibovich et al., 2010) but might also be less responsive to current therapies when advanced (Motzer et al., 2002a; Choueiri et al., 2008; Plimack et al., 2010). Furthermore, pathologists recognize that within individual renal cell tumors there is regional variation with respect to tumor morphology and grade. It is also apparent that significant heterogeneity of clinical behavior exists within a particular histological subtype of RCC. For example, a subset of patients with clear cell RCC are recognized to have limited and indolent metastatic disease, and may not require initiation of systemic treatment for some years (Fisher et al., 2011). In the landmark phase III trial of sunitinib compared with interferon, $\sim 25 \%$ of patients did not benefit from sunitinib treatment, despite all having at least a clear cell component to their tumor histology (Motzer et al., 2007). Furthermore, a recent trial of sunitinib exclusively in patients with RCC as a result of hereditary VHL disease found a response rate of only $33 \%$ in RCCs, and no effect of sunitinib on benign tumors, suggesting a complex relationship between the underlying genetic alteration and treatment of one of its end-targets (Jonasch et al., 2011).

\section{THE CHALLENGE OF GENETIC HETEROGENEITY IN RCC}

Could these results, and the challenges associated with current therapies for mRCC be partly explained on the basis of intra-and 
inter-tumoral heterogeneity? This is the concept that distinct sub-populations of cancer cells exist within and between tumors of individual patients respectively, each with distinct genotypes and phenotypes, as a result of clonal evolution of the tumor (Marusyk and Polyak, 2010; Navin et al., 2011). The underlying mechanisms driving intra- and inter-tumor heterogeneity may be different, but it seems likely that their impact on the ability to deliver personalized medicine in mRCC overlaps. The evidence for each will be summarized in the following paragraphs.

\section{INTRATUMOUR HETEROGENEITY}

Reports of heterogeneity in DNA content within RCCs date back to 1985 (Ljungberg et al., 1985, 1996; Krech et al., 1990); in one study, intra-tumoural heterogeneity of DNA ploidy assessed by flow and static cytometry was found in $71 \%$ of clear cell RCCs (Krech et al., 1990). Some of these studies attempted to correlate spatial variation in DNA ploidy index with prognostic outcomes. Ljungberg et al. (1996) studied multiple samples from each of 200 RCCs and reported a significant proportion of heterogenous tumors (56\%) containing both aneuploid and diploid cell populations. A second study also involved multiple samples from individual RCC nephrectomy specimens, including those of clear cell, papillary, and chromophobe histology, and analyzed DNA content by flow cytometry. A lower prevalence of intra-tumoural heterogeneity was found; 27 of 124 tumors (22\%) contained both diploid and non-diploid populations (Ruiz-Cerda et al., 1999). Neither of these studies observed a relationship between heterogeneous distribution of aneuploidy within individual tumors, which might reflect ongoing genomic instability as opposed to stably aneuploid tumors, and survival. A negative correlation between the number of DNA losses per RCC tumor, as determined by comparative genomic hybridization, and recurrence-free survival has been demonstrated, but this relationship reflects genomic complexity rather than intra-tumor heterogeneity per se (Moch et al., 1996).

After the cloning of the VHL gene, Moch et al. examined intra-tumor heterogeneity with respect to VHL gene status in RCC. In this study, frozen tumor samples from 53 patients with clear cell and papillary RCC were analyzed by FISH and indicated the presence of intra-tumoural, large sub-populations of malignant cells with and without VHL deletion, in at least one tumor (Moch et al., 1998). This finding was supported by results of an earlier study showing heterogeneous loss of chromosome $3 \mathrm{p}$ using conventional cytogenetics (van der Hout et al., 1993). A recent study published in this journal sequenced the VHL gene of paired primary and metastatic clear cell renal tumors stored as paraffin-embedded tissue (Vaziri et al., 2012). Seven of 10 patients' samples (either primary or metastatic, containing $>95 \%$ tumor) were found to have VHL gene mutations, and one patient had VHL gene methylation. Four patients had discordant $V H L$ genotype between primary and metastatic lesions, and VHL gene status also varied within different micro-dissected areas of the primary and metastatic tumors in two patients. Acknowledging the difficulty of identifying true somatic mutations in genetically heterogenous specimens, sequence variations of the VHL gene identified in a subset of genomic DNA samples were independently validated by a highthroughput technique which combines endonuclease scanning and Sanger sequencing (Nickerson et al., 2008). This disparity, and results of another study in which $32 \%$ of mRCC tumors bore no genetic similarity to the primary (Bissig et al., 1999), might suggest that heterogeneous primary tumors result in the outgrowth of a biologically advantageous low frequency sub-clone which establishes the secondary disease site.

Recently we have described the complex somatic mutational, genomic, and transcriptomic landscapes within clear cell RCC tumors from four patients (Gerlinger et al., 2012). Multiple single biopsies of primary and metastatic tumor sites enabled multi-region exome sequencing, revealing that only a minority of somatic mutations were present across all biopsy specimens, and clearly demonstrating the presence of spatial tumor heterogeneity involving nearly all levels of genetic alteration. From this information, a comprehensive phylogenetic tree of branched tumor progression was constructed.

\section{INTER-TUMOR HETEROGENEITY}

Whole exome sequencing of clear cell renal tumors has recently identified a number of candidate cancer genes additional to $V H L$, including PBRM1, SETD2, JARID1C, and UTX (van Haaften et al., 2009; Dalgliesh et al., 2010; Varela et al., 2011; Guo et al., 2012; Larkin et al., 2012). Frequently, these are genes involved in histone and chromatin modification (Larkin et al., 2012). It is apparent though that their mutation rate in clear cell RCC is often low (less than 10\%; http://www.sanger.ac.uk/perl/genetics/CGP/cosmic) and therefore mutations are not commonly shared between patients, at least at the current level of sequencing depth possible. This work indicates the presence of significant inter-tumor genetic heterogeneity in the histological subtype of clear cell RCC, previously thought to be dominated by a driver mutation in $V H L$ (Dalgliesh et al., 2010) and may present an obvious limitation to the "one size fits all" approach to systemic therapy which is currently offered to patients with kidney cancer.

\section{THE IMPACT OF TUMOURAL HETEROGENEITY ON TREATMENT AND RESEARCH}

New evidence such as this clearly has profound implications for clinical practice and research. Inter and intratumour heterogeneity present a major obstacle to further improvements in medical therapy for mRCC. A key issue is the inability to select drug therapy for an individual patient, despite numerous studies investigating candidate biomarkers in RCC (reviewed in Vickers and Heng, 2010). This is in stark contrast to other solid tumor types such as cancers of the breast and lung and melanoma (Slamon et al., 2001; Kwak et al., 2010; Maemondo et al., 2010; Chapman et al., 2011), where patients who will definitely not benefit from targeted treatment are more easily identifiable at the outset. It is possible that limited progress in predictive biomarker discovery and validation in RCC reflects the presence of complex genomic abnormalities which differ within regions of a tumor and between tumor sites. Such intratumour heterogeneity may result in tumor sampling bias and the failure to validate biomarkers discovered through single tumor biopsy genomics analyses. Clinical trial designs which include rigorous tissue collection protocols based on multi-region tumor analyses to define common ubiquitous genetic changes that may serve as more robust predictors of disease biology, 
such as those used by the Personalized RNA interference to Enhance the Delivery of Individualized Cytotoxic and Targeted therapeutics (PREDICT) consortium (Swanton et al., 2010) are required, but are often complex and demanding in terms of human and financial resources.

The mechanisms of resistance to antiVEGF and anti-mTOR treatments in mRCC are incompletely understood, but an obvious question which arises from regional genomic variability in tumors is whether intra-tumoural heterogeneity itself fosters treatment resistance and therapeutic failure (Carter et al., 2006; Walther et al., 2008; McClelland et al., 2009; Swanton et al., 2009; Gerlinger and Swanton, 2010; Birkbak et al., 2011; Lee et al., 2011; Roylance et al., 2011). The presence of intra-tumor heterogeneity and its associated multiple tumor dependencies suggest the worrying prospect that multiple drugs will be required to treat one heterogeneous tumor.

\section{CONCLUSION}

In summary, there is a small but increasing body of literature supporting intra- and inter-tumor heterogeneity in RCC, predominantly in the clear cell subtype. Their clinical relevance has not been properly addressed in the era of modern genomic techniques. However, it is our view that the potential impact of tumoural heterogeneity on effective therapy for this disease is such that it is an area worthy of intensive research. Efforts must be focused on adaptation of clinical trial design and the further advancement and accessibility of novel tumor genomics analyses derived from multiple tumor sites to facilitate an understanding of ITH and the clonal evolution of disease through treatment.

\section{REFERENCES}

Birkbak, N. J., Eklund, A. C., Li, Q., McClelland, S. E., Endesfelder, D., Tan, P., Tan, I. B., Richardson, A. L., Szallasi, Z., and Swanton, C. (2011). Paradoxical relationship between chromosomal instability and survival outcome in cancer. Cancer Res. 71, 3447-3452.

Bissig, H., Richter, J., Desper, R., Meier, V., Schraml, P., Schaffer, A. A., Sauter, G., Mihatsch, M. J., and Moch, H. (1999). Evaluation of the clonal relationship between primary and metastatic renal cell carcinoma by comparative genomic hybridization. Am. J. Pathol. 155, 267-274.

Carter, S. L., Eklund, A. C., Kohane, I. S., Harris, L. N., and Szallasi, Z. (2006). A signature of chromosomal instability inferred from gene expression profiles predicts clinical outcome in multiple human cancers. Nat. Genet. 38, 1043-1048.
Chapman, P. B., Hauschild, A., Robert, C., Haanen, J. B., Ascierto, P., Larkin, J., Dummer, R., Garbe, C., Testori, A., Maio, M., Hogg, D., Lorigan, P., Lebbe, C., Jouary, T., Schadendorf, D., Ribas, A., O’Day, S. J., Sosman, J. A., Kirkwood, J. M., Eggermont, A. M., Dreno, B., Nolop, K., Li, J., Nelson, B., Hou, J., Lee, R. J., Flaherty, K. T., and McArthur, G. A. (2011). Improved survival with vemurafenib in melanoma with BRAF V600E mutation. N. Engl. J. Med. 364, 2507-2516.

Choueiri, T. K., Plantade, A., Elson, P., Negrier, S., Ravaud, A., Oudard, S., Zhou, M., Rini, B. I., Bukowski, R. M., and Escudier, B. (2008). Efficacy of sunitinib and sorafenib in metastatic papillary and chromophobe renal cell carcinoma. J. Clin. Oncol. 26, 127-131.

Coppin, C., Porzsolt, F., Awa, A., Kumpf, J., Coldman, A., and Wilt, T. (2005). Immunotherapy for advanced renal cell cancer. Cochrane Database Syst. Rev. 1, CD001425.

Dalgliesh, G. L., Furge, K., Greenman, C., Chen, L., Bignell, G., Butler, A., Davies, H., Edkins, S., Hardy, C., Latimer, C., Teague, J., Andrews, J., Barthorpe, S., Beare, D., Buck, G., Campbell, P. J., Forbes, S., Jia, M., Jones, D., Knott, H., Kok, C. Y., Lau, K. W., Leroy, C., Lin, M. L., McBride, D. J., Maddison, M., Maguire, S., McLay, K., Menzies, A., Mironenko, T., Mulderrig, L., Mudie, L., O’Meara, S., Pleasance, E., Rajasingham, A., Shepherd, R., Smith, R., Stebbings, L., Stephens, P., Tang, G., Tarpey, P. S., Turrell, K., Dykema, K. J., Khoo, S. K., Petillo, D., Wondergem, B., Anema, J., Kahnoski, R. J., Teh, B. T., Stratton, M. R., and Futreal, P. A. (2010). Systematic sequencing of renal carcinoma reveals inactivation of histone modifying genes. Nature 463, 360-363.

Del Bufalo, D., Ciuffreda, L., Trisciuoglio, D., Desideri, M., Cognetti, F., Zupi, G., and Milella, M. (2006). Antiangiogenic potential of the mammalian target of rapamycin inhibitor temsirolimus. Cancer Res. 66, 5549-5554.

Escudier, B., Eisen, T., Stadler, W.M., Szczylik, C., Oudard, S., Siebels, M., Negrier, S., Chevreau, C., Solska, E., Desai, A. A., Rolland, F., Demkow, T., Hutson, T. E., Gore, M., Freeman, S., Schwartz, B., Shan, M., Simantov, R., and Bukowski, R. M. (2007a). Sorafenib in advanced clear-cell renal-cell carcinoma. N. Engl. J. Med. 356, 125-134.

Escudier, B., Pluzanska, A., Koralewski, P., Ravaud, A., Bracarda, S., Szczylik, C., Chevreau, C., Filipek, M., Melichar, B., Bajetta, E., Gorbunova, V., Bay, J. O., Bodrogi, I., Jagiello-Gruszfeld, A., and Moore, N. (2007b). Bevacizumab plus interferon alfa-2a for treatment of metastatic renal cell carcinoma: a randomised, double-blind phase III trial. Lancet 370, 2103-2111.

Fingar, D. C., Richardson, C. J., Tee, A. R., Cheatham, L., Tsou, C., and Blenis, J. (2004). mTOR controls cell cycle progression through its cell growth effectors S6K1 and 4E-BP1/eukaryotic translation initiation factor 4E. Mol. Cell. Biol. 24, 200-216.

Fisher, R. A., Pender, A., Thillai, K., Chowdhury, S., Pickering, L. M., St. Rose, S., Gore, M. E., and Larkin, J.M.G. (2011). Observation prior to systemic therapy in patients with metastatic renal cell carcinoma in the kinase inhibitor era. J. Clin. Oncol. 29, abstr. 4630.

Gerlinger, M., Rowan, A., Horswell, S., Larkin, J., Endesfelder, D., Gronroos, E. P. M., Matthews, N., Stewart, A., Mcdonald, N., Butler, A., Jones, D., Raine, K., Santos, C., Varela, I., Nohadani, M., Eklund, A., Spencer-Dene, B., Clark, G., Pickering, L., Stamp, G., Gore, M., Szallasi, Z., Downward, J., Futreal, P.A., and
Swanton, C. (2012). Intratumor heterogeneity and branched evolution revealed by multiregion sequencing. N. Engl. J. Med. 366, 883-893.

Gerlinger, M., and Swanton, C. (2010). How Darwinian models inform therapeutic failure initiated by clonal heterogeneity in cancer medicine. Br. J. Cancer 103, 1139-1143.

Guo, G., Gui, Y., Gao, S., Tang, A., Hu, X., Huang, Y., Jia, W., Li, Z., He, M., Sun, L., Song, P., Sun, X., Zhao, X., Yang, S., Liang, C., Wan, S., Zhou, F., Chen, C., Zhu, J., Li, X., Jian, M., Zhou, L., Ye, R., Huang, P., Chen, J., Jiang, T., Liu, X., Wang, Y., Zou, J., Jiang, Z., Wu, R., Wu, S., Fan, F., Zhang, Z., Liu, L., Yang, R., Liu, X., Wu, H., Yin, W., Zhao, X., Liu, Y., Peng, H., Jiang, B., Feng, Q., Li, C., XIe, J., Lu, J., Kristiansen, K., Li, Y., Zhang, X., Li, S., Wang, J., Yang, H., Cai, Z., and Wang, J. (2012). Frequent mutations of genes encoding ubiquitinmediated proteolysis pathway components in clear cell renal cell carcinoma. Nat. Genet. 44, 17-19.

Harris, D. T. (1983). Hormonal therapy and chemotherapy of renal-cell carcinoma. Semin. Oncol. 10, 422-430.

Hudes, G., Carducci, M., Tomczak, P., Dutcher, J., Figlin, R., Kapoor, A., Staroslawska, E., Sosman, J., McDermott, D., Bodrogi, I., Kovacevic, Z., Lesovoy, V., Schmidt-Wolf, I. G., Barbarash, O., Gokmen, E., O’Toole, T., Lustgarten, S., Moore, L., and Motzer, R. J. (2007). Temsirolimus, interferon alfa, or both for advanced renal-cell carcinoma. N. Engl. J. Med. 356, 2271-2281.

Jemal, A., Siegel, R., Xu, J., and Ward, E. (2010). Cancer statistics, 2010. CA Cancer J. Clin. 60, 277-300.

Jonasch, E., McCutcheon, I. E., Waguespack, S. G., Wen, S., Davis, D. W., Smith, L. A., Tannir, N. M., Gombos, D. S., Fuller, G. N., and Matin, S. F. (2011). Pilot trial of sunitinib therapy in patients with von Hippel-Lindau disease. Ann. Oncol. 22, 2661-2666.

Kaelin, W. G. Jr. (2007). The von Hippel-Lindau tumor suppressor protein and clear cell renal carcinoma. Clin. Cancer Res. 13, 680s-684s.

Kim, W. Y., and Kaelin, W. G. (2004). Role of VHL gene mutation in human cancer. J. Clin. Oncol. 22, 4991-5004.

Krech, R. H., Baretton, G., Fonatsch, C., Diebold, J., Fruchtnicht, W., and Lohrs, U. (1990). Comparison of flow cytometric, static cytometry and tumor cytogenetic investigation results human renal cell carcinomas. Verh. Dtsch. Ges. Pathol. 74, 228-232.

Kwak, E. L., Bang, Y. J., Camidge, D. R., Shaw, A. T., Solomon, B., Maki, R. G., Ou, S. H., Dezube, B. J., Janne, P. A., Costa, D. B., Varella-Garcia, M., Kim, W. H., Lynch, T. J., Fidias, P., Stubbs, H., Engelman, J. A., Sequist, L. V., Tan, W., Gandhi, L., Mino-Kenudson, M., Wei, G. C., Shreeve, S. M., Ratain, M. J., Settleman, J., Christensen, J. G., Haber, D. A., Wilner, K., Salgia R., Shapiro, G. I., Clark, J. W., and Iafrate, A. J. (2010). Anaplastic lymphoma kinase inhibition in non-smallcell lung cancer. N. Engl. J. Med. 363, 1693-1703.

Larkin, J., Goh, X. Y., Vetter, M., Pickering, L., and Swanton, C. (2012). Epigenetic regulation in RCC: opportunities for therapeutic intervention? Nat. Rev. Urol. 9, 147-155.

Lee, A. J., Endesfelder, D., Rowan, A. J., Walther,A., Birkbak, N.J., Futreal, P.A., Downward, J., Szallasi,Z., Tomlinson, I.P., Howell, M., Kschischo, M., and Swanton, C. (2011). Chromosomal instability confers intrinsic multidrug resistance. Cancer Res. 71, 1858-1870.

Leibovich, B. C., Blute, M. L., Cheville, J. C., Lohse, C. M., Frank, I., Kwon, E. D., Weaver, A. L., Parker, A. S., 
and Zincke, H. (2003). Prediction of progression after radical nephrectomy for patients with clear cell renal cell carcinoma: a stratification tool for prospective clinical trials. Cancer 97, 1663-1671.

Leibovich, B. C., Lohse, C. M., Crispen, P. L., Boorjian, S. A., Thompson, R. H., Blute, M. L., and Cheville, J. C. (2010). Histological subtype is an independent predictor of outcome for patients with renal cell carcinoma. J. Urol. 183, 1309-1315.

Ljungberg, B., Mehle, C., Stenling, R., and Roos, G. (1996). Heterogeneity in renal cell carcinoma and its impact no prognosis - a flow cytometric study. Br. J. Cancer $74,123-127$.

Ljungberg, B., Stenling, R., and Roos, G. (1985). DNA content in renal cell carcinoma with reference to tumor heterogeneity. Cancer 56, 503-508.

Lubensky, I. A., Schmidt, L., Zhuang, Z., Weirich, G., Pack, S., Zambrano, N., Walther, M. M., Choyke, P., Linehan, W. M., and Zbar, B. (1999). Hereditary and sporadic papillary renal carcinomas with c-met mutations share a distinct morphological phenotype. Am. J. Pathol. 155, 517-526.

Maemondo, M., Inoue, A., Kobayashi, K., Sugawara, S., Oizumi, S., Isobe, H., Gemma, A., Harada, M., Yoshizawa, H., Kinoshita, I., Fujita, Y., Okinaga, S., Hirano, H., Yoshimori, K., Harada, T., Ogura, T., Ando, M., Miyazawa, H., Tanaka, T., Saijo, Y., Hagiwara, K., Morita, S., and Nukiwa, T. (2010). Gefitinib or chemotherapy for non-small-cell lung cancer with mutated EGFR. N. Engl. J. Med. 362, 2380-2388.

Martignoni, G., Pea, M., Gobbo, S., Brunelli, M., Bonetti, F., Segala, D., Pan, C. C., Netto, G., Doglioni, C., Hes, O., Argani, P., and Chilosi, M. (2009). Cathepsin-K immunoreactivity distinguishes MiTF/TFE family renal translocation carcinomas from other renal carcinomas. Mod. Pathol. 22, 1016-1022.

Marusyk, A., and Polyak, K. (2010). Tumor heterogeneity: causes and consequences. Biochim. Biophys. Acta 1805, 105-117.

McClelland, S. E., Burrell, R. A., and Swanton, C. (2009). Chromosomal instability: a composite phenotype that influences sensitivity to chemotherapy. Cell Cycle 8 , 3262-3266.

Moch, H., Presti, J. C. Jr., Sauter, G., Buchholz, N., Jordan, P., Mihatsch, M. J., and Waldman, F. M. (1996). Genetic aberrations detected by comparative genomic hybridization are associated with clinical outcome in renal cell carcinoma. Cancer Res. 56, $27-30$.

Moch, H., Schraml, P., Bubendorf, L., Richter, J., Gasser, T. C., Mihatsch, M. J., and Sauter, G. (1998). Intratumoral heterogeneity of von Hippel-Lindau gene deletions in renal cell carcinoma detected by fluorescence in situ hybridization. Cancer Res. 58, 2304-2309.

Motzer, R. J., Bacik, J., Mariani, T., Russo, P., Mazumdar, M., and Reuter, V. (2002a). Treatment outcome and survival associated with metastatic renal cell carcinoma of non-clear-cell histology. J. Clin. Oncol. 20, 2376-2381.

Motzer, R. J., Bacik, J., Murphy, B. A., Russo, P., and Mazumdar, M. (2002b). Interferon-alfa as a comparative treatment for clinical trials of new therapies against advanced renal cell carcinoma. J. Clin. Oncol. 20, 289-296.

Motzer, R. J., Bander, N. H., and Nanus, D. M. (1996). Renal-cell carcinoma. N. Engl. J. Med. 335, 865-875.
Motzer, R.J., Escudier, B., Oudard, S., Hutson, T.E., Porta, C., Bracarda, S., Grunwald, V., Thompson, J.A., Figlin, R. A., Hollaender, N., Kay, A., and Ravaud, A. (2010). Phase 3 trial of everolimus for metastatic renal cell carcinoma: final results and analysis of prognostic factors. Cancer 116, 4256-4265.

Motzer, R. J., Hutson, T. E., Tomczak, P., Michaelson, M. D., Bukowski, R. M., Rixe, O., Oudard, S., Negrier, S., Szczylik, C., Kim, S. T., Chen, I., Bycott, P. W., Baum, C. M., and Figlin, R. A. (2007). Sunitinib versus interferon alfa in metastatic renal-cell carcinoma. $\mathrm{N}$. Engl. J. Med. 356, 115-124.

Navin, N., Kendall, J., Troge, J., Andrews, P., Rodgers, L., McIndoo, J., Cook, K., Stepansky, A., Levy, D., Esposito, D., Muthuswamy, L., Krasnitz, A., McCombie, W. R., Hicks, J., and Wigler, M. (2011). Tumour evolution inferred by single-cell sequencing. Nature 472, 90-94.

Nickerson, M. L., Jaeger, E., Shi, Y., Durocher, J. A., Mahurkar, S., Zaridze, D., Matveev, V., Janout, V., Kollarova, H., Bencko, V., Navratilova, M., SzeszeniaDabrowska, N., Mates, N., Mukeria, A., Holcatova, I., Schmidt, L. S., Toro, J. R., Karami, S., Hung, R., Gerard, G. F., Linehan, W. M., Merino, M., Zbar, B., Boffetta, P., Brennan, P., Rothman, N., Chow, W. -. H., Waldman, F. M., and Moore, L. E. (2008). Improved identification of von Hippel-Lindau gene alterations in clear cell renal tumors. Clin. Cancer Res. 14, 4726-4734.

Nickerson, M. L., Warren, M. B., Toro, J. R., Matrosova, V., Glenn, G., Turner, M. L., Duray, P., Merino, M., Choyke, P., Pavlovich, C. P., Sharma, N., Walther, M., Munroe, D., Hill, R., Maher, E., Greenberg, C., Lerman, M. I., Linehan, W. M., Zbar, B., and Schmidt, L. S. (2002). Mutations in a novel gene lead to kidney tumors, lung wall defects, and benign tumours of the hair follicle in patients with the Birt-Hogg-Dube syndrome. Cancer Cell 2, 157-164.

Pan, C. C., Chen, P. C., and Chiang, H. (2004). Overexpression of KIT (CD117) in chromophobe renal cell carcinoma and renal oncocytoma. Am. J. Clin. Pathol. 121, 878-883.

Plimack, E. R., Jonasch, E., Bekele, B. N., Qiao, W., Tamboli, P., Ng, C. S., and Tannir, N. M. (2010). Sunitinib in papillary renal cell carcinoma: results from a single-arm phase II study. J. Clin. Oncol. 28, abstr. 4604.

Reuter, V. E. (2006). The pathology of renal epithelial neoplasms. Semin. Oncol. 33, 534-543.

Ricketts, C., Woodward, E. R., Killick, P., Morris, M. R., Astuti, D., Latif, F., and Maher, E. R. (2008). Germline SDHB mutations and familial renal cell carcinoma. $J$. Natl. Cancer Inst. 100, 1260-1262.

Rini, B. I., Escudier, B., Tomczak, P., Kaprin, A., Hutson, T. E., Szczylik, C., Tarazi, J. C., Rosbrook, B., Kim, S., and Motzer, R. J. (2011). Axitinib versus sorafenib as second-line therapy for metastatic renal cell carcinoma: results of phase III AXIS trial. J. Clin. Oncol. 29, abstr. 4503.

Rini, B. I., Halabi, S., Rosenberg, J. E., Stadler, W. M., Vaena, D. A., Ou, S. S., Archer, L., Atkins, J. N., Picus, J., Czaykowski, P., Dutcher, J., and Small, E. J. (2008). Bevacizumab plus interferon alfa compared with interferon alfa monotherapy in patients with metastatic renal cell carcinoma: CALGB 90206. J. Clin. Oncol. 26, 5422-5428.

Roylance, R., Endesfelder, D., Gorman, P., Burrell, R. A., Sander, J., Tomlinson, I., Hanby, A. M., Speirs,
V., Richardson, A. L., Birkbak, N. J., Eklund, A. C., Downward, J., Kschischo, M., Szallasi, Z., and Swanton, C. (2011). Relationship of extreme chromosomal instability with long-term survival in a retrospective analysis of primary breast cancer. Cancer Epidemiol. Biomarkers Prev. 20, 2183-2194.

Ruiz-Cerda, J.L., Hernandez, M., Sempere, A., O'Connor, J. E., Kimler, B. F., and Jimenez-Cruz, F. (1999). Intratumoral heterogeneity of DNA content in renal cell carcinoma and its prognostic significance. Cancer $86,664-671$.

Schmelzle, T., and Hall, M. N. (2000). TOR, a central controller of cell growth. Cell 103, 253-262.

Schmidt, L., Duh, F. M., Chen, F., Kishida, T., Glenn, G., Choyke, P., Scherer, S. W., Zhuang, Z., Lubensky, I., Dean, M., Allikmets, R., Chidambaram, A., Bergerheim, U. R., Feltis, J. T., Casadevall, C., Zamarron, A., Bernues, M., Richard, S., Lips, C. J., Walther, M. M., Tsui, L. C., Geil, L., Orcutt, M. L., Stackhouse, T., Lipan, J., Slife, L., Brauch, H., Decker, J., Niehans, G., Hughson, M. D., Moch, H., Storkel, S., Lerman, M. I., Linehan, W. M., and Zbar, B. (1997). Germline and somatic mutations in the tyrosine kinase domain of the MET proto-oncogene in papillary renal carcinomas. Nat. Genet. 16, 68-73.

Slamon, D. J., Leyland-Jones, B., Shak, S., Fuchs, H., Paton, V., Bajamonde, A., Fleming, T., Eiermann, W., Wolter, J., Pegram, M., Baselga, J., and Norton, L. (2001). Use of chemotherapy plus a monoclonal antibody against HER2 for metastatic breast cancer that overexpresses HER2. N. Engl. J. Med. 344, 783-792.

Sternberg, C. N., Davis, I. D., Mardiak, J., Szczylik, C., Lee, E., Wagstaff, J., Barrios, C. H., Salman, P., Gladkov, O. A., Kavina, A., Zarba, J. J., Chen, M., McCann, L., Pandite, L., Roychowdhury, D. F., and Hawkins, R. E. (2010). Pazopanib in locally advanced or metastatic renal cell carcinoma: results of a randomized phase III trial. J. Clin. Oncol. 28, 1061-1068.

Swanton, C., Larkin, J. M., Gerlinger, M., Eklund, A. C., Howell, M., Stamp, G., Downward, J., Gore, M., Futreal, P. A., Escudier, B., Andre, F., Albiges, L., Beuselinck, B., Oudard, S., Hoffmann, J., Gyorffy, B., Torrance, C. J., Boehme, K. A., Volkmer, H., Toschi, L., Nicke, B., Beck, M., and Szallasi,Z. (2010). Predictive biomarker discovery through the parallel integration of clinical trial and functional genomics datasets. Genome Med. 2, 53-63. Swanton, C., Nicke, B., Schuett, M., Eklund, A. C., Ng, C., Li, Q., Hardcastle, T., Lee, A., Roy, R., East, P., Kschischo, M., Endesfelder, D., Wylie, P., Kim, S. N., Chen, J. G., Howell, M., Ried, T., Habermann, J. K., Auer, G., Brenton, J. D., Szallasi, Z., and Downward, J. (2009). Chromosomal instability determines taxane response. Proc. Natl. Acad. Sci. U.S.A. 106,8671-8676.

Thomas, G. V., Tran, C., Mellinghoff, I. K., Welsbie, D. S., Chan, E., Fueger, B., Czernin, J., and Sawyers, C. L. (2006). Hypoxia-inducible factor determines sensitivity to inhibitors of mTOR in kidney cancer. Nat. Med. 12, 122-127.

Toro, J. R., Nickerson, M. L., Wei, M. H., Warren, M. B., Glenn, G. M., Turner, M. L., Stewart, L., Duray, P., Tourre, O., Sharma, N., Choyke, P., Stratton, P., Merino, M., Walther, M. M., Linehan, W. M., Schmidt, L. S., and Zbar, B. (2003). Mutations in the fumarate hydratase gene cause hereditary leiomyomatosis and renal cell cancer in families in North America. Am. J. Hum. Genet. 73, 95-106.

UK, C. R. (2011). Cancer Statistics. Available at: http:// info.cancerresearchuk.org/cancerstats/ 
van der Hout, A. H., van den Berg, E., van der Vlies, P., Dijkhuizen, T., Storkel, S., Oosterhuis, J. W., de Jong, B., and Buys, C. H. (1993). Loss of heterozygosity at the short arm of chromosome 3 in renal-cell cancer correlates with the cytological tumour type. Int. J. Cancer 53, 353-357.

van Haaften, G., Dalgliesh, G. L., Davies, H., Chen, L., Bignell, G., Greenman, C., Edkins, S., Hardy, C., O’Meara, S., Teague, J., Butler, A., Hinton, J., Latimer, C., Andrews, J., Barthorpe, S., Beare, D., Buck, G., Campbell, P. J., Cole, J., Forbes, S., Jia, M., Jones, D., Kok, C. Y., Leroy, C., Lin, M. L., McBride, D. J., Maddison, M., Maquire, S., McLay, K., Menzies, A., Mironenko, T., Mulderrig, L., Mudie, L., Pleasance, E., Shepherd, R., Smith, R., Stebbings, L., Stephens, P., Tang, G., Tarpey, P. S., Turner, R., Turrell, K., Varian, J., West, S., Widaa, S., Wray, P., Collins, V. P., Ichimura, K., Law, S., Wong, J., Yuen, S. T., Leung, S. Y., Tonon, G., DePinho, R. A., Tai, Y. T., Anderson, K. C., Kahnoski, R. J., Massie, A., Khoo, S. K., Teh, B. T., Stratton, M. R., and Futreal, P. A. (2009). Somatic mutations of the histone H3K27 demethylase gene UTX in human cancer. Nat. Genet. 41, 521-523.

Varela, I., Tarpey, P., Raine, K., Huang, D., Ong, C. K., Stephens, P., Davies, H., Jones, D., Lin, M. L., Teague, J., Bignell, G., Butler, A., Cho, J., Dalgliesh, G. L.,
Galappaththige, D., Greenman, C., Hardy, C., Jia, M., Latimer, C., Lau, K. W., Marshall, J., McLaren, S., Menzies, A., Mudie, L., Stebbings, L., Largaespada, D. A., Wessels, L. F., Richard, S., Kahnoski, R. J., Anema, J., Tuveson, D. A., Perez-Mancera, P. A., Mustonen, V., Fischer, A., Adams, D. J., Rust, A., Chan-on, W., Subimerb, C., Dykema, K., Furge, K., Campbell, P. J., Teh, B. T., Stratton, M. R., and Futreal, P. A. (2011). Exome sequencing identifies frequent mutation of the SWI/SNF complex gene PBRM1 in renal carcinoma. Nature 469, 539-542.

Vaziri, S. A., Tavares, E. J., Golshayan, A. R., Rini, B. I., Aydin, H., Zhou, M., Sercia, L., Wood, L., Ganapathi, M. K., Bukowski, R. M., and Ganapathi, R. (2012). Differing von Hippel Lindau genotype in paired primary and metastatic tumors in patients with clear cell renal cell carcinoma. Front. Oncol. 2:51. doi: 10.3389/ fonc.2012.00051

Vickers, M. M., and Heng, D. Y. (2010). Prognostic and predictive biomarkers in renal cell carcinoma. Target Oncol. 5, 85-94.

Walther, A., Houlston, R., and Tomlinson, I. (2008). Association between chromosomal instability and prognosis in colorectal cancer: a meta-analysis. Gut 57, 941-950.

Yagoda, A., and Bander, N. H. (1989). Failure of cytotoxic chemotherapy, 1983-1988, and the emerging role of monoclonal antibodies for renal cancer. Urol. Int. 44, 338-345.

Yamazaki, K., Sakamoto, M., Ohta, T., Kanai, Y., Ohki, M., and Hirohashi, S. (2003). Overexpression of KIT in chromophobe renal cell carcinoma. Oncogene 22, 847-852.

Yusenko, M. V., Zubakov, D., and Kovacs, G. (2009). Gene expression profiling of chromophobe renal cell carcinomas and renal oncocytomas by Affymetrix GeneChip using pooled and individual tumours. Int J. Biol. Sci. 5, 517-527.

Received: 20 April 2012; accepted: 01 May 2012; published online: 18 May 2012.

Citation: Fisher R, Larkin J and Swanton C (2012) Inter and intratumour heterogeneity: a barrier to individualized medical therapy in renal cell carcinoma? Front. Oncol. 2:49. doi: 10.3389/fonc.2012.00049

This article was submitted to Frontiers in Genitourinary Oncology, a specialty of Frontiers in Oncology.

Copyright (c) 2012 Fisher, Larkin and Swanton. This is an open-access article distributed under the terms of the Creative Commons Attribution Non Commercial License, which permits non-commercial use, distribution, and reproduction in other forums, provided the original authors and source are credited. 